\title{
James Madison and Judicial Review
}

$I^{\text {T has long been the quest of critical students of our constitutional }}$ development to find a definite expression from some of its founding fathers, stating that it was the deliberate intention of the Federal Convention to provide for judicial review and that this intention was definitely expressed in certain clauses of the Constitution. In other words, that this power of the courts according to the mtention of the framers of the Constitution is as deliberately and definitely expressed by the language of the Constitution as the powers of the President and of the Congress.

It has not been difficult to find numerous statements in the records of the Federal Convention, ${ }^{1}$ in those of the ratifying conventions, ${ }^{2}$ and in the Federalist papers $^{3}$ to the effect that the courts in actual controversial cases would pass upon the constitutionality of legislation. These statements are indubitably clear as to the expectations of certain nembers of these conventions but there still remained the question of a specific basis for the power of the courts to declare legislative acts unconstitutional. Was the basis for this power of the courts merely judicial convention or precedent based upon the practice of the Judicial Committee of the Privy Council, the Courts of Westminster ${ }^{4}$ and the state courts under the first state constitutions? ${ }^{5}$ Was this power inherent in the judicial function? If so, why was it not universally exercised? Was it an inherent principle of a written con-

1 I Farrand, The Records of the Federal Convention of 1787 (1911) 21, 26, 27, $96,97,98,100,101,109 ; 2$ ibid. at $21,22,27,28,29,73,74,75,76,78,80,136$, $139,156,157,186,298,299,376,391,428,430 ; 3$ ibid. at 128, 220, 240, 369, 370, 383.

2 I Elutot, The Debates in the Several State Conventions on the Adoption of the Federal Constitution (1881) 380; 2 ibia. at 131, 196, 271, 295, 445, 446, 489; 3 ibid. at $205,324,325,539,541,548,553,564,567,570 ; 4$ ibid. at 155, 156, 257, $258,382,383,393$.

3 The Federauist, Nos. 39, 79, 80 (Lodge ed. 1888) passim.

4 Sir Charles Pratt (afterwards Lord Camden) while Attorney General said with reference to colonial legislation: "At the same time we are of opinion that there may be cases in which particular provisions may be void $a b$ initio though other parts of the law may be valid, as in clauses where any act of Parliament may be contraversed or any legal right of a private subject bound without his consent. These are cases the decision of which does not depend on the exercise of a discretionary prerogative, but may arise judicially and must be determined by general rules of law and the constitution of England. And upon this ground it is, that in some instances whole acts of assembly have been declared void in the courts of Westminster Hall, and by his Majesty in Council upon appeals from the plantations." The Statutes at Large of Pennsyuvania From 1682 to 1801 (1898) 735-736.

5 Hatnes, The American Doctrine of Judictal Supremacy (1932) 88-121. 
stitution? If so, why has it not been applied under all written constitutions? Was it derived from a fundamental law? Was it a usurpation by American courts? Was it imtentionally granted in express terms in the Constitution? If so, in what clauses is it found?

Some very able treatises have been written by historians, lawyers, and political scientists, arguing the pros and cons of the basis of judicial review. ${ }^{6}$ There is also a long list of articles by specialists in constitutional law attempting to prove or disprove the constitutionality of judicial review. ${ }^{7}$ The substance of all this literature is, according to some of the writers, that the leading members of the Federal Convention expressed themselves in favor of judicial review, and, according to others, that the above statement should be discounted very materially. Nowhere has it been shown that any of the framers have said that this power of the courts is granted in certain clauses of the Constitution.

Beard, after a very careful analysis of the evidence, says: "We are justified in asserting that twenty-five members of the Convention favored or at least accepted some form of judicial control. This number understood that federal judges could refuse to enforce unconstitutional legislation." Corwin discounts the evidence presented by Beard and concludes that he is "not convinced by Mr. Beard's data that the Convention of 1787 thought itself to be concluding the constitutional question decided in Marbury v. Madison. On the contrary I believe that the Convention regarded that question as still as [an?] open one when it adjourned." "Furthermore," he says, "by far the two most important members of this group are Hamilton and Madi-

${ }^{6}$ See Beard, The Supreate Court and the Constitution (1926); 1 \& 2 Boudin, Governament by Judrclary (1932); Corwin, The Doctrine of Judictal Review (1914) ; Dougherty, Power of Federal Judiciary Over Legrslation (1912); Haines, op. cit. supta note 5; McLadugrin, The Courts, The Constitution and Parties (1912) ; Meigs, The Rejation of the Judiciary to the Constitution (1919); Roe, OUR JUdTCtal OLIGARCHY (1912).

7 Beard, The Supreme Court-Usurper or Grantee (1912) 27 Por. Scr. Q. 1; Burns, Madison's Theory of Judicial Review (1936) $24 \mathrm{KY}$. L. J. 412; Corwin, The Higher Law Background of American Constitutional Law (1928) 42 HARv. L. REv. 149; Corwin, The Establishment of Judicial Review (1910) 9 MICH. L. Rev. 102; Corwin, The Basic Doctrine of American Constitutional Law (1914) 12 ibid. 247; Melvin, The Iudicial Bulwark of the Constitution (1910) 8 AM. Pox. Scr. Rev. 167; Trickett, The Great Usurpation (1906) 40 AM. L. Rev. 356; Trickett, Judicial Dispensation from Congressional Statutes (1907) 41 ibid. 65; Trickett, Judicial Nullification of Acts of Corgress (1907) 185 N. AM. REv. 848.

8 BEARD, op. cit. supra note 6 , at 51 .

9 Book Review (1913) 7 AM. Por. Scr. Rev. 329, 330. 
son, the former of whom apparently became a convert to the idea under discussion between the time of writing Federalist 33 and Federalist 78 and the latter of whom is proved by the very language which Mr. Beard quotes to have been unfavorable both in 1788 and 1789."10 It is a little disconcerting to find two great political scientists and scholars quoting the same language of the father of the Constitution and reaching diametrical conclusions.

There is also the contention that Madison was favorable to judicial review at the time of drafting and adopting the Constitution but that later he changed his mind. ${ }^{11}$ I am persuaded that this confusion results from a misinterpretation of some of Madison's contentions made both during and following the convention. No proposition calls for less defense than that Madison was afraid of legislative power and that he believed that American constitutions would suffer most from this source. He said in the Convention that "Experience in all the States had evinced a powerful tendency in the Legislature to absorb all power into its vortex. This was the real source of danger to the American Constitutions; \& suggested the necessity of giving every defensive authority to the other departments that was consistent with republican principles." 12

\section{MADISON'S POSITION IN REGARD TO JUDICIAL REVIEW IN 1787}

Notice that Madison says that he "suggested the necessity of giving every defensive authority to the other departments. ..." What were the other departments than the legislative department? They were the executive and the judiciary. What was this "defensive authority" that he suggested these two departments should have? $\mathrm{He}$ suggested repeatedly a veto to be exercised by the President associated with a convement number of the national judiciary called a . Council of Revision. ${ }^{13}$ He said: "We must introduce the Checks, which will destroy the measures of an interested majority-in this view a negative in the Ex. [Executive] is not only necessary for its own safety, but for the safety of a minority in Danger of oppression from an unjust and interested majority-The independent condition of the Ex. [Executive] who has the Eyes of all Nations on him will render him a just Judge-add the Judiciary and increase the respec-

$10 \mathrm{Ibid}$. at $330-331$.

11 See HAINES, op. cit. supra note 5, at 234 et seq.

122 FaRRAND, op. cit. supra note 1 , at 74 .

131 ibid. at 94, 95, 98, 99, 104, 106, 107, 109, 110,131, 138, 144; 2 ibid. at 73, 74, $77,298,301,586,587$. 
tability." 14 The Council of Revision, if it had been established, would have been exclusively legislative in character and tantamount to a third house. Its veto was to be absolute and this is why it was thought necessary to have the judges associated with the President to prevent the giving of such a power to one man. James Wilson in discussing a qualified negative by the Executive said: "He was for varying the proposition in such a manner as to give the Executive \& Judiciary jointly an absolute negative." 15 The Council of Revision was proposed four times during the proceedings of the Convention and was defeated each time. The result was that the President alone was given only a suspensive veto. Madison was forced to accept a suspensive veto as the "defensive authority" in the executive against legislative usurpation.

There remained the other part of his suggestion that there was "the necessity of giving every defensive authority to the other departments." What was to be the "defensive authority" to be given to the judicial department? Throughout the discussion of the Council of Revision it was understood that the courts were to exercise the power of passing on the constitutionality of legislation. The opponents of the Council of Revision used this fact as an argument against the establishment of the Council. Speaking of the Council of Revision, Gerry said he doubted "whether the Judiciary ought to form a part of it, as they will have a sufficient check agst. encroachments on their own department by their exposition of the laws, which involved a power of deciding on their Constitutionality." 16 Luther Martin, who was opposed to the Council of Revision, said: "A knowledge of mankind, and of Legislative affairs cannot be presumed to belong in a higher deger degree [sic] to the Judges than to the Legislature. And as to the Constitutionality of laws, that point will come before the Judges in their proper official character. In this character they lave a negative on the laws. Join them with the Executive in the Revision and they will have a double negative."17 Mason, who favored the Council of Revision, replying to Martin, said: "It had been said [by Mr. L. Martin] that if the judges were joined in this check on the laws, they would have a double negative, since in their expository capacity of Judges they would have one negative. $\mathrm{He}$ would reply that in this capacity they could impede in one case only,

141 ibid. at 108.

15 Ibid. at 98, 105.

$10 \mathrm{Ibid}$. at 97.

172 ibid. at 76. 
the operation of laws. They could declare an unconstitutional law void. But with regard to every law however unjust oppressive or pernicious, which did not come plainly under this description [unconstitutional], they would be under the necessity as Judges [not as members of the Council] to give it a free course. He wished the further use to be made of the Judges, of giving aid in preventing every improper law."18

Here Mason, an advocate of the establishment of the Council of Revision and a supporter of Madison and Wilson on this proposition, frankly and clearly states that the Council of Revision is not a substitute for judicial review. He states that he wants both and clearly distinguishes between the functions of the judges as members of the Council of Revision and their function as judges on the bench deciding cases. In the former capacity, he says, their veto would extend to "every improper law" and in the latter it would be restricted to constitutionality in cases only. Could any proposition be clearer than that concurrent with the debate on the Council of Revision it was understood that judicial review was already a settled matter?

Now did Madison understand this to be the case? He certainly knew what was being said because he was writing the records of the debates. He heard Mason make this distinction between the function of the Council and the function of the judges in their judicial capacity. He heard Mason say that the judges were to be used in both capacities. Would he have remained silent and thereby permitted Mason to misrepresent his own proposition before the Convention? This is unthinkable. Does this amount to his taking a position favorable to judicial review in 1787 , distinguished authority to the contrary notwithstanding? Does it not also mean that this was the defensive authority in the judiciary that he had in mind?

But it may be said that this is mere argument and inference. Did Madison say anywhere in 1787 that he understood that the court would exercise the power of judicial review? When the prohibition on ex post facto laws was under discussion Madison understood that the scope of the prohibition extended to civil matters as well as criminal and when it was further proposed that an additional limitation be made to include civil matters he asked, "Is not that already done by the prohibition of ex post facto laws, which will oblige the Judges to declare such interference null \& void?"19 In other words, on Au-

18 Ibid. at 78.

19 Ibid. at 440 . 
gust 28, 1787, Madison calls the attention of the Convention to the fact that the judges will declare unconstitutional legislation null and void. Does he oppose it? No. Then must he not be favorable to it? The fact is that it is his understanding that the courts have already been given this power.

Again on September 12th when the question whether the states might not evade the prohibition against export duties was being debated he stated that judicial review was the remedy. Gorham of Massachusetts and Langdon of New Hampshire asked the question: "How was redress to be obtained in case duties should be laid beyond the purpose expressed?" Madison replied: "There will be the same authority as in other cases. The jurisdiction of the supreme court must be the source of redress." This he said was the "provision made by the plan against injurious acts of the states. ${ }^{20}$ Here he definitely states that the "plan" provides for judicial review.

Moreover, Madison took steps in the Convention to safeguard this power of the courts. When the question of how the Constitution was to be ratified was being debated in the Federal Convention, whether by legisIatures or conventions, Madison opposed ratification by the legislatures on the ground that it would establish legislative supremacy and endanger the doctrine of judicial review. He said "it would be a novel \& dangerous doctrine that a Legislature could change the constitution under which it held its existence." 21

In his argument for ratification by conventions, he said that " $\mathrm{He}$ considered the difference between a system founded on the Legislatures only, and one founded on the people, to be the true difference between a league or treaty, and a Constitution. The former in point of moral obligation might be as inviolable as the latter. In point of political operation, there were two important distinctions in favor of the latter. 1. A Law violating a treaty ratified by a preexisting law, might be respected by the Judges as a law, though an unwise or perfidious one. A law violating a constitution established by the people themselves would be considered by the Judges as null \& void. 2. The doctrine laid down by the law of Nations in the case of treaties is that a breach of any one article by any of the parties, frees the other parties from their engagements. In the case of a union of people under one Constitution, the nature of the pact has always been understood to exclude such an interpretation. Comparing the two modes in 
point of expediency he thought all the considerations which recommended this Convention in preference to Congress for proposing the reform were in favor of State Conventions in preference to the Legislatures for examiming and adopting it." 22

It is clear from this quotation that Madison did not want legislatures, either the Congress or state legislatures, to have anything to do with making the Constitution. Why? Because it would make the Constitution a treaty. He said a "law violating a treaty" might be respected by the judges, but a "law violating a constitution" would be declared null and void. In other words, Madison said that if you want to be certain that judicial review will be exercised, ratify the Constitution by conventions. This was Madison's advice on July 23, 1787 and the Convention followed it. Hence on this date both Madison and the Convention went on record as deliberately adopting the method of ratification that would guarantee the principle of judicial review.

In Federalist No. 39, written in 1787, Madison again explained that the line of federalism was to be maintained by judicial review. He said: "It is true that in controversies relating to the boundary between the two jurisdictions [the union and the states], the tribunal which is ultimately to decide, is to be established under the general government. .. . The decision is to be impartially made, according to the rules of the Constitution; and all the usual and most effectual precautions are taken to secure this impartiality. Some such tribunal is clearly essential to prevent an appeal to the sword and a dissolution of the compact. . . "23 Here Madison repeats in substance what he had said in the Convention, that judicial review is necessary to prevent "a dissolution of the compact." This, then, was Madison's unequivocal position on judicial review in 1787 .

It should be noticed that he says that the "controversies relating to the boundary between the two jurisdictions" are to be ultimately decided by the tribunal which became the Supreme Court. This means that controversies involving the line of federalism are ultimately to be decided by the Supreme Court. Several matters are involved in this statement. By using the word "ultimately" he means that such controversies could be decided in the first instance in lower courts. In other words, it was the province of all courts to exercise this power in cases which involved the line of federalism.

22 Ibid. at 93 .

23 The Federalist, No. 39 (Lodge ed. 1888) 238-239. 
In the next place such controversies would involve the acts of the Congress as well as those of the states. Either the Congress or a state legislature could create such a controversy by transcending its powers. It could not be presumed that either would always act constitutionally, nor that either would always be constitutionally wrong. To decide such controversies according to the Constitution in all instances, the courts would have to have the power to declare the acts of both the Congress and the states unconstitutional. In some instances the acts of the Congress would be involved, and in others those of the states. It is obvious, of course, that practically every case involving the constitutionality of an act of Congress or of a state legislature is a controversy over the line of federalism. Madison says the courts were to decide these controversies, the Supreme Court ultimately.

WAS JUDICIAT REVIEW DELIBERATELY GRANTED BY THE CONSTITUTION?

In a letter to Jefferson in 1823 Madison discusses the line of federalism and the possible means of maintaining it. He first shows that it was impossible to make "a precise demarkation of the boundary between the Federal \& the State Authorities." 24 After surveying "the difficulty in tracing the boundary between the General \& State Gov.ts," he says, "the problem remains for maintaining it in practice; particularly in cases of Judicial cognizance." 25 It is important to notice that he is discussing the problem of maintaining the lime of federalism in cases of judicial cognizance. This is precisely the problem of judicial review.

He then shows that no other device than judicial review would suffice as a proper solution of this problem. He says: "[1] To refer every point of disagreement to the people in Conventions would be a process too tardy, too troublesome, \& too expensive; besides its tendency to lessen a salutary veneration for an instrument so often calling for such explanatory interpositions. [2] A paramount or even a definitive Authority in the individual States, would soon make the Constitution \& laws different in different States, and thus destroy that equality \& uniformity of rights \& duties which form the essence of the Compact; to say nothing of the opportunity given to the States individually of involving by their decisions the whole Union in foreign Contests. [3] To leave conflicting decisions to be settled be-

249 The Writings of Ja3res Madison (Hunt's ed. 1910) 140.

25 Ibid. 
tween the Judicial parties could not promise a happy result. The end must be a trial of strength between the Posse headed by the Marshal and the Posse headed by the Sheriff. [4] Nor would the issue be safe if left to a compromise between the two Gov.ts the case of a disagreement between branches of the same Gov.t. In the latter case neither party being able to consummate its will without the concurrence of the other, there is a necessity on both to consult and to accommodate. Not so, with different Gov.ts each possessing every branch of power necessary to carry its purpose into compleat effect. It here becomes a question between Independent Nations, with no other dernier resort than physical force. [5] Negotiation might indeed in some instances avoid this extremity; but how often would it happen, among so many States, that an unaccommodating spirit in some would render that resource unavailing." 26

After discussing these five possibilities as means of maintaining the boundary between the general and state governments in practice and showing their inadequacy in each instance, he concludes by saying, "We arrive at the agitated question whether the Judicial Authority of the U.S. be the constitutional resort for determining the line between the federal \& State jurisdictions. Believing as I do that the General Convention regarded a provision within the Constitution for deciding in a peaceable \& regular mode all cases arising in the course of its operation, as essential to an adequate System of Govt. that it intended the Authority vested in the Judicial Department as a final resort in relation to the States, for cases resulting to it in the exercise of its functions ... ; and that this intention is expressed by the articles declaring that the federal Constitution \& laws shall be the supreme law of the land, and that the Judicial Power of the U.S. shall extend to all cases arising under them." ${ }^{27}$ Here Madison states that it was the intention of the Convention to provide within the Constitution for judicial review and that it expressed this intention in the supreme law of the land clause and in the clause extending the scope of judicial power to all cases arising under the Constitution and the laws passed in pursuance of it. It is important to notice that Madison is discussing the constitutional means of maintaining "the lime between the federal \& State jurisdictions." This is not merely the problem of the relation of the states to the Union any more than it is the problem of the relation of the Union to the states. He specifically states it is "the line between the federal \& State jurisdictions" 
that is to be maintained by the courts. Can this line be inaintained by preventing only the states froin crossing it? Is not the Union just as likely to cross it by entering the jurisdiction of the states? Would the line be maintained if such acts could not be declared unconstitutional? Madison is not discussing the method of maintaining the supremacy of the acts of the Congress. He calls it "the line between the federal \& State jurisdictions." It is the constitutional line between the powers of the Umion and those of the states. This line could conceivably be maintained only by keeping both the Union and the states within their respective jurisdictions. Madison says the courts were made the constitutional authorities to do this. Hence, they inust have the power to declare the acts of both governments, national and state, transcending their jurisdictions, null and void, in order to perform this function.

It is settled then, according to Madison, that the Convention deliberately provided for judicial review by a definite grant expressed in the clauses of the Constitution and that it understood that the language used in these clauses expressly granted this power to the judicial department. Since Madison recorded the minutes of the Convention, it is unthinkable that he misunderstood the Convention. Furthermore, no one would tolerate for a monent the idea that Madison in this letter of 1823 would misrepresent the intention of the Convention. It follows, then, that the American courts, in passing upon the constitutionality of legislation in actual cases, have not exercised a power which was not deliberately granted by the Constitution.

DID MAADISON CHANGE HIS POSITION OF 1787 IN REGARD TO JUDICIAL REVIEW?

Would Madison's own words be authority on this subject? In this same letter of 1823 , referring to the part previously quoted, he said: "Believing moreover that this was the prevailing view of the subject when the Constitution was adopted \& put into execution; that it has so continued thro' the long period which has elapsed; and that even at this time an appeal to a national decision would prove that no general change has taken place: thus believing I have never yielded my original opinion indicated in the 'Federalist' No. 39...."2s

Madison says here that he had never clianged his original opinion indicated in 1787 in Federalist No. 39. His original opinion was, "It 
is true that in controversies relating to the boundary between the two jurisdictions, the tribunal which is ultimately to decide, is to be established under the general government." 20 The "tribunal" which he mentions, is obviously the Supreme Court, for which, it will be recalled, the Convention made provision in the Constitution but left its establishment to the Congress. Of course, this tribunal could not decide controversies between the two jurisdictions of our federal system without exercising review over legislation of both the national government and those of the states. Madison himself then said in 1823 that he had never changed his mind, the opinions of others to the contrary notwithstanding. ${ }^{30}$

In 1829 Madison in replying to Calhoun's argument that the states were the parties to the compact or Constitution said, "A fundamental error lies in supposing the State Govts. to be the parties to the Constitutional compact from which the Govt. of the U.S. results." 31 He further stated: "The plain fact of the case is that the Constitution of the U.S. was created by the people composing the respective States, who alone had the right; that they organized the Govt. into Legis. Ex. \& Judicy. depts. [Legislative, Executive, and Judiciary departments] delegating thereto certain portions of power to be exercised over the whole, and reserving the other portions to themselves respectively. As these distinct portions of power were to be exercised by the General Govt. \& by the State Govts.; by each within limited spheres; and as of course controversies concerning the boundaries of their power wd. [would] happen, it was provided that they should be decided by the Supreme Court of the U.S. so constituted as to be as impartial as it could be made by the mode of appointment \& responsibility for the Judges." 32

It is important to notice that in this quotation Madison says that the states were not the parties to the compact but the people of the states. This is done to refute Calhoun's argument that the states were the final arbiters in settling conflicts of jurisdiction between the Union and the states. Then he says it was provided that this was to be the function of the Supreme Court. Here again he states that judicial review was provided in the Constitution. Again it should be noticed that as late as 1829 he had not changed his mind.

In 1830 in a letter to M. S. Hurlbert, Madison says: "That the

20 THE FEDERATIST, No. 39 (Lodge ed. 1888) 238-239.

30 See HADNES, op. cit. supra note 5, at 234 et seq.

319 The Writngs of James Madison, op. cit. supra note 24 at 351.

32 Ibid. at $352-353$. 
supreme powers of Govt. being divided between different Govts. and controversies as to the landmarks of jurisdiction being unavoidable, provision for a peaceable $\&$ authoritative decision of thein was obviously essential:

"That, to leave this decision to the States, numerous as they were \& with a prospective increase, would evidently result in conflicting decisions subversive of the common Govt. and of the Union itself:

"That, according to the actual provision against such calamities, the Constitution \& laws of the U. S. are declared to be paramount to those of the individual States, \& an appellate supremacy is vested in the Judicial power of the U. S." ${ }^{\text {"3 }}$ Here again he says judicial supremacy over the acts of both the national and state governments is vested in the courts.

In a letter to Senator Robert Y. Hayne, dated April 3d or 4th, 1830, dissenting from the Senator's views expressed in recent addresses, Madison again refers to the calamities that might result from disputes between the Union and states and says: "Against such fatal consequences the Constitution undertakes to guard by declaring that the Constitution \& laws of the States in their united capacity shall have effect, anything in the Constitution or laws of any State in its individual capacity to the contrary notwithstanding, by giving to the Judicial authority of the U.S. an appellate supremacy in all cases arising under the Constitution. ..."34 Again Madison said in a letter to Everett in 1830 that judicial supremacy was given in all cases arising under the Constitution. He further stated that "Those who have denied or doubted the supremacy of the judicial powers ... seem not to have sufficiently adverted to the utter inefficiency of a supremacy in a law of the land, without a supremacy in the exposition \& execution of the law...."35 By exposition he means judicial review.

According to Madison, who knew the intention of the Convention better than any other member, judicial review was intentionally and deliberately granted to the courts in specific clauses of the Constitution. Also, according to his own words, he never changed his mind on this question. And Gaillard Hunt said of Madison: "No man ever accused him of untruth or meanness."

THE UNIVERSTTY OF TEXAS.

C. Perry Patterson.

33 Ibid. at 374.

34 Ibid. at 385-386, n. 2.

35 Ibid. at 397-398.

361 ibid. at xxxii. 